\title{
Spotted cucumber beetle Diabrotica undecimpunctata howardi Barber (Insecta: Coleoptera: Chrysomelidae) ${ }^{1}$
}

\author{
Harsimran Kaur Gill, Gaurav Goyal, and Jennifer Gillett-Kaufman²
}

\section{Introduction}

Spotted cucumber beetle, Diabrotica undecimpunctata howardi Barber, is a major agricultural pest of North America. Another name for the spotted cucumber beetle is "southern corn rootworm” (Bessin 2010). Many Diabrotica species cause damage to field crops, especially corn (Zea mays L.), making these beetles a major agricultural concern. Because of the subterranean nature of their larvae, these insects are hard and expensive to control (Krysan and Miller 1986).

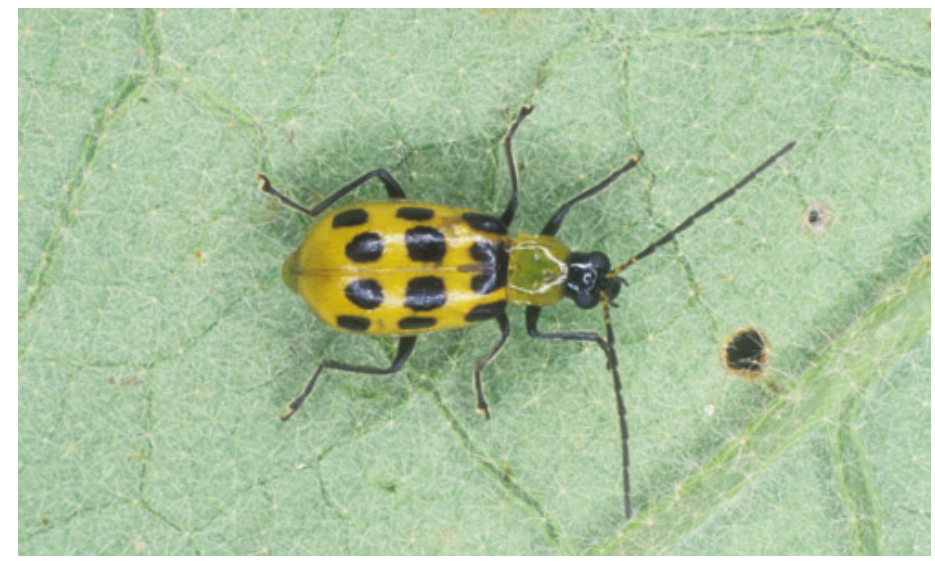

Figure 1. The spotted cucumber beetle, Diabrotica undecimpunctata howardi Barber.

Credits: James Castner, Entomology and Nematology Department, University of Florida.
In Florida, there are three main species of cucumber beetles that attack cucurbits. Spotted cucumber beetle is more common in North Florida, while the banded cucumber beetle (Diabrotica balteata, Figure 2) is more commonly found in southern Florida. The striped cucumber beetle (Acalymma vittatum) may also be found in some areas but is not very common (Webb 2010). Spotted cucumber beetle overwinters in southern states and disperses to northern states annually (Capinera 2008). The beetles are a major concern to cantaloupe (muskmelon) (Cucumis melo L.) and cucumber (Cucumis sativus L.) growers due to their ability to vector the bacteria that causes bacterial wilt of cucurbits (Bessin 2010).

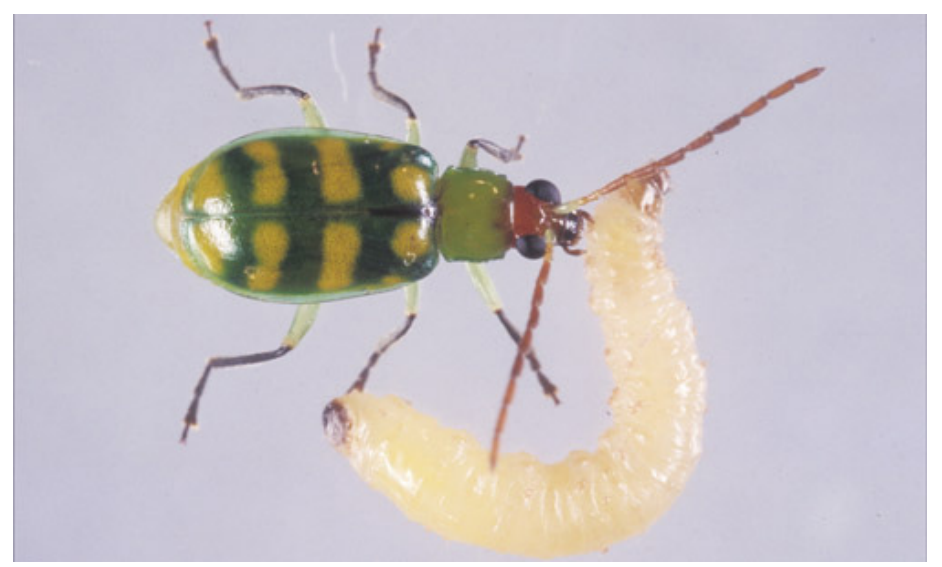

Figure 2. Larvae and adult banded cucumber beetle, Diabrotica balteata LeConte.

Credits: Lyle Buss, Entomology and Nematology Department, University of Florida.

1. This document is EENY1008, one of a series of the Entomology and Nematology Department, UF/IFAS Extension. Original publication date September 2013. Visit the EDIS website at http://edis.ifas.ufl.edu.

2. Harsimran Kaur Gill, post doctoral research associate; Gaurav Goyal, post doctoral research associate; and Jennifer Gillett-Kaufman, assistant Extension scientist; Entomology and Nematology Department, UF/IFAS Extension, Gainesville, FL 32611. 


\section{Distribution}

Spotted cucumber beetles are native insects distributed throughout the United States from Mexico to Canada, although they are most abundant and destructive in southern regions (Capinera 2008, Day 2009). These beetles are not troublesome in sandy soils (Sorensen 1999).

\section{Description and Life Cycle}

Unmated adults overwinter under leaves and debris around woodlands and buildings. Adults leave their hiding sites in late March and females oviposit from late April to early June. Larvae feed on roots and stems under the soil where they mature for two to four weeks before pupating. Immature stages cause plant damage by boring into plant stem base and roots (Brust and House 1990, Capinera 2008). First generation adult emergence occurs from late June to early July. Generally, there are two generations per year, but a single generation has been reported in Oregon, and three in southern California and Alabama. Approximately six to nine weeks are required to complete one life cycle. Spotted cucumber beetle can pass through two and sometimes a partial third generation per year (Sorensen 1999).

\section{Eggs}

Beetles become active in mid-spring and quickly start locating host plants for feeding and egg deposition. Females oviposit throughout the field and eggs typically hatch within 6-9 days (Webb 2010, Alston and Worwood 2008) and can take up to 30 days with under low temperature conditions (Capinera 2008). Eggs are yellow, oval shaped laid in clusters of 25-50 below leaf surface, and measure about $0.7 \mathrm{~mm}$ long and $0.5 \mathrm{~mm}$ wide (Capinera 2008, Sorensen 1999). Adult females deposit eggs in soil crevices at or near the base of cucurbit plants. Freshly laid eggs are completely dependent on soil moisture for their survival (Krysan 1976). After eggs hatch, larvae start feeding on plant roots (Bessin 2010, Capinera 2008).

\section{Larvae}

Mature larvae are wormlike and almost $12 \mathrm{~mm}$ long. They have a slender, white body with three pairs of long, brown legs. Larvae have a brown head capsule measuring 0.3, 0.4, and $0.6 \mathrm{~mm}$ in width for first, second and third instars, respectively (Capinera 2008). A dark brown plate is located on the dorsal side of the last segment of larvae (Alston and Worwood 2008, Sorensen 1999, Webb 2010). The larvae require seven, five, and four days for development of first, second and third instars, respectively (Capinera 2008) or about total of 2-3 $1 / 2$ weeks for complete larval development (Webb 2010). The last stage larva constructs a small chamber in the soil and pupates within that chamber (Alston and Worwood 2008).

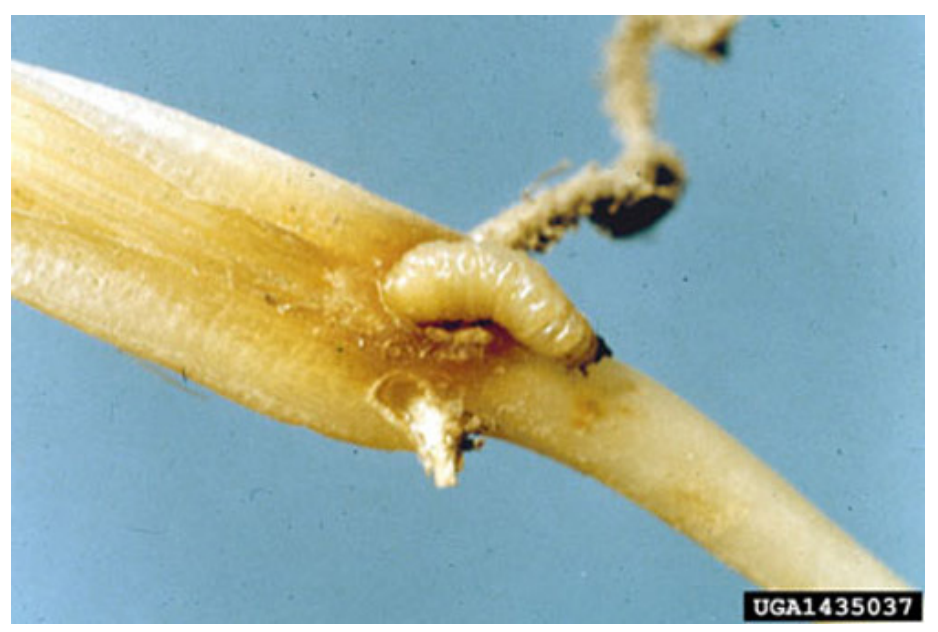

Figure 3. Larvae of the spotted cucumber beetle, Diabrotica undecimpunctata howardi Barber.

Credits: Clemson University - USDA Cooperative Extension Slide Series, Bugwood.org.

\section{Pupae}

Pupae are white initially, but turn yellowish with age and start looking like adults. Pupae measure about $7.5 \mathrm{~mm}$ long and $4.5 \mathrm{~mm}$ wide. A pair of stout spines is present on the tip of the abdomen and smaller spines are found on the dorsal side of other abdominal segments (Capinera 2008). Pupal period varies from 6-10 days (Capinera 2008, Webb 2010).

\section{Adults}

The spotted cucumber beetle is $6.4 \mathrm{~mm}$ long and yellowgreen with 12 black spots on the elytra (forewings) (Alston and Worwood 2008, Bessin 2010, Capinera 2008, Sorensen 1999, Webb 2010). The head and legs are black, and the beaded black antennae are about $1.6 \mathrm{~mm}$ long (Sorensen 1999). Adults are most active in the morning and late afternoon (Webb 2010). The beetle overwinters during the adult stage near buildings, wood lots or in fence rows (Bessin 2010). Overwintering adults become active once the temperature reaches $15-20^{\circ} \mathrm{C}$. Capinera (2008) reported that adults are long lived: 60 days in summer and up to 200 days in winter. Adults start ovipositing 2-3 weeks after emergence.

\section{Damage}

These beetles cause agricultural damage by feeding on roots, seedlings, flowers and foliage, and transmitting disease. Adult feeding on cucurbit plants or transplants has been reported to result in wilting and reduced yield. Larvae feed on roots and tunnel through stems (Sorensen 1999). The larvae can cause severe damage to small plants, but less 
damage to large plants with fully developed root systems (Bessin 2010, Webb 2010). Feeding by larvae may enhance the incidence of Fusarium wilt disease (Capinera 2008). The beetles also damage crops by causing scarring on fruits, which decreases their market value (Synder 2012). Larvae cause some injury to surface or rind of fruits which are in contact with soil. These larvae are sometimes also called "rindworms". Fruit of smooth-skinned melons is more susceptible to damage by beetles, especially before the skin becomes too hard to penetrate (Capinera 2008).

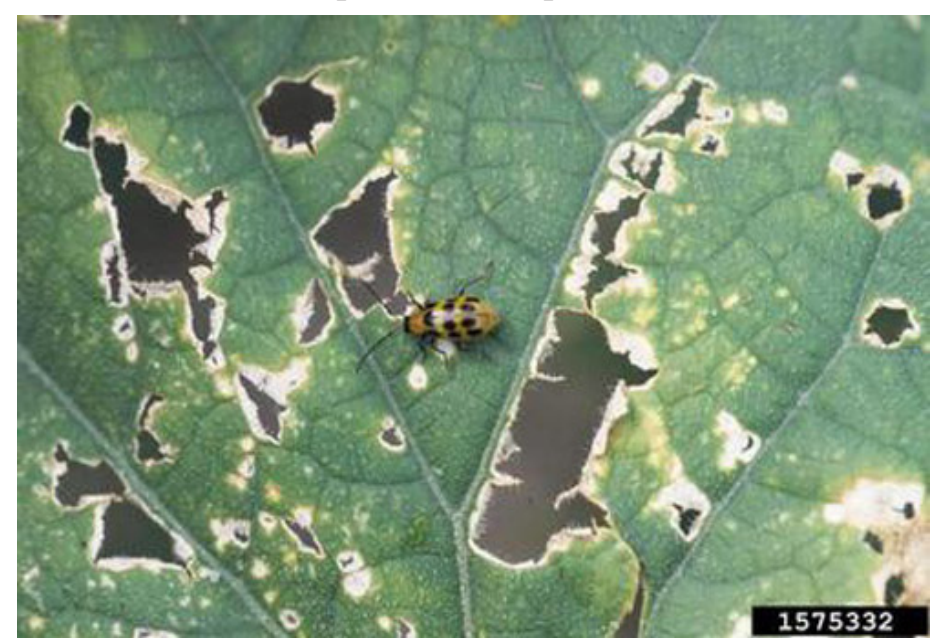

Figure 4. Cucumber anthracnose and feeding damage from the spotted cucumber beetle, Diabrotica undecimpunctata howardi Barber Credits: Gerald Holmes, Valent USA Corporation, Bugwood.org

The bacterium Pseudomonas lachrymans that causes "bacterial wilt" can survive in the gut of beetles in winters and it is a serious concern in central and eastern United States (Alston and Worwood 2008). In the spring, these beetles spread the bacterium either through their feces or contaminated mouthparts. Feeding damage on young leaves or cotyledons leads to open entry points for the pathogen. The bacterium multiplies quickly within the plant's vascular system, and starts producing blockages that cause wilting (Bessin 2010) in many cucurbits (watermelons are not affected) (Webb 2010). Spotted cucumber beetles also vector other diseases like squash mosaic virus, cucumber mosaic virus, bean mosaic virus, maize chlorotic mottle and machlo virus (Alston and Worwood 2008).

\section{Host Plants}

These beetles cause agricultural damage by feeding on roots, seedlings, flowers and foliage, and transmitting disease. Adult feeding on cucurbit plants or transplants has been reported to result in wilting and reduced yield. Larvae feed on roots and tunnel through stems (Sorensen 1999). The larvae can cause severe damage to small plants, but less damage to large plants with fully developed root systems
(Bessin 2010, Webb 2010). Feeding by larvae may enhance the incidence of Fusarium wilt disease (Capinera 2008). The beetles also damage crops by causing scarring on fruits, which decreases their market value (Synder 2012). Larvae cause some injury to surface or rind of fruits which are in contact with soil. These larvae are sometimes also called "rindworms". Fruit of smooth-skinned melons is more susceptible to damage by beetles, especially before the skin becomes too hard to penetrate (Capinera 2008).

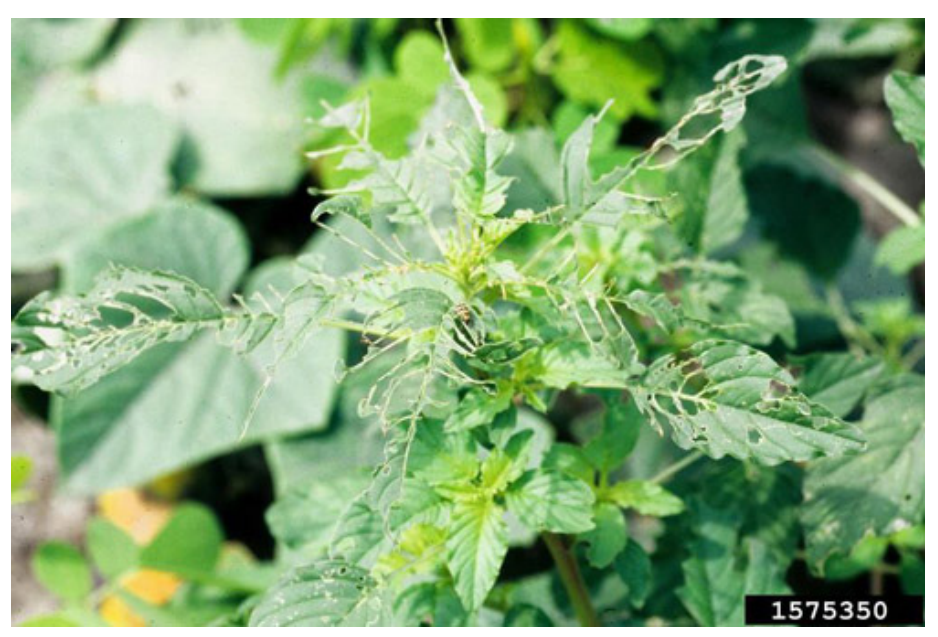

Figure 5. Adult of the spotted cucumber beetle, Diabrotica undecimpunctata howardi Barber, on pigweed in a field of cucumber.

Credits: Gerald Holmes, Valent USA Corporation, Bugwood.org.

\section{Monitoring}

Monitoring is a critical part of any cucumber beetle control program. Plants should be monitored as soon as they emerge or are transplanted, to avoid severe damage to seedlings. An example of a monitoring plan would be to monitor five plants at five different spots in the field (total 25 plants) and calculate the average number of beetles per plant. Control measures are recommended if numbers exceed five or more per mature plant. Control measures should be followed immediately if any unacceptable beetle damage occurs on young plants (Alston and Worwood 2008).

\section{Management}

In large commercial cantaloupe or cucumber production, early treatment is crucial for beetle management. Research must be focused and coordinated to accelerate biological control strategies for cucumber beetles (Toepfer et al. 2009). 


\section{Biological Control}

Some of the important natural enemies that attack cucumber beetles are tachinid flies (Celatoria diabrotica (Shimer)), fungus (Beauveria), and a nematode (Howardula benigna (Cobb)) (Capinera 2008). In Utah, biocontrol agents that attack cucumber beetles are soldier beetles, ground beetles, braconid wasps, tachinid flies, and entomopathogenic nematodes. Beneficial insects can attack adults, eggs and larvae on plants or on the soil surface. Entomopathogenic nematodes have been found to suppress larvae and pupae of beetles in soil (Alston and Worwood 2008).

Diverse community of predators (harvestmen or "daddy long legs", ground and rove beetles, several kinds of spiders, predatory mites, and bats) may be useful for biological control of beetles rather than relying only on one species (Synder 2012). Although there is no solid evidence that pathogens effectively control adult beetles, but fungal pathogens and entomopathogenic nematodes are available commercially to control larvae. These bio-pesticides and their soil-drenching formulations have shown some action against cucumber beetles larvae in soil (Choo et al 1996, Ellers-Kirk et al. 2000, Reed et al. 1986).

\section{Cultural control}

Planting and seed rates: Early plowing-disking (which removes unwanted plants and discourages egg laying), delayed planting, and heavy seed rates help to minimize the impact of these beetles (Sorensen 1999). Avoid planting cucurbit crops near preferred host plants of beetle larvae (e.g. beans, corn, small grains and other grasses, and weeds) (Alston and Worwood 2008). Planting can be delayed until the beetles have already dispersed and deposited most of their eggs. This tactic can help to reduce the need for insecticides (Capinera 2008).

For small scale cucurbits operations (e.g., for home gardens), small plants can be protected by mechanical means. Row covers, screens or cones around small plants are useful for keeping beetles away (Bessin 2010). It was reported that a combination of companion plants such as radish (Raphanus sativus L.), tansy (Tanacetum vulgare L.), and nasturtium (Tropaeolum spp. L.) and aluminum plastic mulch increased cantaloupe yield and vine cover and reduced cucumber beetle populations. Use of row crops like buckwheat (Fagopyrum esculentum Moench), cowpea (Vigna unguiculata (L.), and sweetclover (Melilotus officinalis (L.)) was also effective at controlling cucumber beetle populations by attracting beneficial insects, which in turn increased cantaloupe yield (Cline et al. 2008, Simon and Synder 2005).

\section{Mulches}

Fewer spotted cucumber beetles were found on zucchini plants in plots where sunn hemp (Crotalaria juncea L.) was interplanted as living mulch compared with bare-ground (with no sunn hemp) plots (Hinds and Hooks 2013). It was reported that aluminum plastic mulches are effective at repelling beetles and aphids from plants. Using mulch and drip irrigation helps reduce soil moisture under fruits, reducing beetle feeding as well (Alston and Worwood 2008). Lower cucumber beetle density was found on cucumber plants grown in richly-mulched soil compared with soils with less organic matter (Yardim et al 2006). This could be because organic matter fosters diverse beneficial soil microorganism community that triggers the plants internal defenses (Zehnder et al. 1997).

Straw mulches were also effective at managing beetles in many ways: slowing down beetle movement, providing refuge for predators (wolf spiders), and providing food for springtails and other insects (Snyder and Wise 2000, Williams and Wise 2003. Decomposers (e.g., springtails) are important non-pest prey for spiders, and help to boost up spiders populations (Halaj and Wise 2002). A care to be taken while using straw mulch is that should be free from any kind of weeds and herbicide residues.

\section{Trap crops, baits and sanitation}

The purpose of trapping is to lure beetles away from the "main crop" by means of attractive colors and odors. The plants of the Cucurbitaceae family release high concentrations of cucurbitacin and other volatiles in order to defend themselves from herbivores. However, these chemicals are attractive to cucumber beetles so these plants can be used as trap crops. Trap crops should be planted two weeks before main crops along the border or strip adjacent to the main crops. Luna and Xue (2009) reported that field edges are the favorite areas where cucumber beetles aggregate (Luna and Xue 2009). Because of the timing, beetles are first attracted to the trap crop rather than main crop. Treat the trap crops with insecticides before the adults start laying eggs. Traps can be baited with different types of pheromones, kairomones, botanical pesticides or attractants which help to keep beetle populations under control (Alston and Worwood 2008). Lures or attractants are designed for detecting beetles when they are at low densities or hard to locate. Indole, cinnamaldehyde alone or in combination with trimethoxybenzene are attractive kairomones and have been used experimentally under field conditions to attract 
beetles (Capinera 2008). Webb (2010) and Capinera (2008) reported that fields should be free from any kind of weeds and grasses.

\section{Plant resistant varieties}

Cucumber beetles are attracted to host plants by the chemical cucurbitacin. This chemical is used as a defense against less-specialized herbivores and gives a bitter flavor to cucurbits (Deheer and Tallamy 1991). These beetles ingest cucurbitacin, and it becomes incorporated into their bodies and making them distasteful to predators, which help to gain protection from predators and parasitioids (Gould and Massey, 1984, Tallamy et al. 1998). So, growers should select cucurbit varieties with lower cucrbitacin levels to decrease their attractiveness for cucumber beetles.

\section{Organic chemicals}

Kaolin clay, pyrethrum and spinosad (not all formulations of spinosad are organic based) are some of the organic chemicals that can be used to manage cucumber beetles to some extent (Synder 2012).

\section{Chemical Control}

It is best to combine insecticides with other management options such as cultural and biological control for longterm management. It is also important to rotate the chemicals with different modes of action to avoid development of pesticide resistance in beetles (Alston and Worwood 2008). Beetles are most active in the spring, so application of foliar insecticides may be required twice a week during that time of year (Bessin 2010). Unlike most cucurbits, watermelon is not susceptible to wilt diseases (Webb 2010), protection is only necessary when beetle population is high and plants are small (Bessin 2010). A foliar insecticide application at the cotyledon stage will hinder beetle feeding. Additional foliar applications may be needed to prevent cucumber mosaic and bacterial wilt diseases, depending on beetle intensity (Sorensen 1999).

\section{Selected References}

Alston DG, Worwood DR. 2008. Western striped cucumber beetle, Western spotted cucumber beetle (Acalymma trivitatum and Diabrotica undecipunctata undecipunctata). Utah Pests Fact Sheets. ENT-118-08. Utah State University Extension and Utah Plant Pest Diagnostic Laboratory. (12 Sep 2013)

Bessin R. 2010. Cucumber beetles. ENTFACT-311. College of Agriculture Food and Environment, University of Kentucky, Lexington, KY. (12 Sep 2013)
Brust GE, House GJ. 1990. Influence of soil texture, soil moisture, organic cover, and weeds on oviposition preference of Southern corn rootworm (Coleoptera: Chrysomelidae). Environmental Entomology 19: 966-971.

Capinera JL. 2008. Spotted Cucumber Beetle or Southern Corn Rootworm, Diabrotica undecimpunctata Mannerheim (Coleoptera: Chrysomelidae). Encyclopedia of Entomology 3519-3522.

Choo HY, Koppenhofer AM, Kaya HK. 1996. Combination of two entomopathogenic nematode species for suppression of an insect pest. Journal of Economic Entomology 89: 97-103.

Cline GR, Sedlacek JD, Hillman SL, Parker SK, Silvernail AF. 2008. Organic management of cucumber beetles in watermelon and muskmelon production. HortTechnology 18: 436-444.

Day E. 2009. Cucumber Beetles. Virginia Corporate Extension and Virginia State University, VA. (12 Sep 2013)

Deheer CJ, Tallamy DW. 1991. Affinity of spotted cucumber beetle (Coleoptera: Chrysomelidae) larvae to cucurbitacins. Environmental Entomlogy 20: 1173-1175.

Ellers-Kirk CD, Fleischer SJ, Snyder RH, Lynch JP. 2000. Potential of entomopathogenic nematodes for biological control of Acalymma vittatum (Coleoptera: Chrysomelidae) in cucumbers grown in conventional and organic soil management systems. Journal of Economic Entomology 93: 605-612.

Gould F, Massey A. 1984. Cucurbitacins and predation of the spotted cucumber beetle, Diabrotica undecimpunctata howardi. Entomologia Experimentalis et Applicata 36: 273-278.

Halaj J, Wise DH. 2002. Impact of a detrital subsidy on trophic cascades in a terrestrial grazing food web. Ecology 83: 3141-3151.

Hinds J, Hooks CRR. 2013. Population dynamics of arthropods in sunn-hemp zucchini interplanting system. Crop Protection 53: 6-12.

Krysan JL. 1976. Moisture relationships of the egg of the southern corn root worm, Diabrotica undecimpunctata howardi (Coleoptera: Chrysomelidae). Entomologia Experimentalis et Applicata 20: 154-162. 
Krysan J, Miller TA. 1986. Methods of study of pest Diabrotica. pp. 260. Springer- Verlag publisher, NY.

Luna JM, Xue L. 2009. Aggregation behavior of Western spotted cucumber beetle (Coleoptera: Chrysomelidae) in vegetable cropping systems. Environmental Entomology 38: 809-814.

Pedersen AB, Godfrey LD. 2011. Field and vegetable crops as hosts of larval western spotted cucumber beetle (Coleoptrea: Chrysomelidae). Environmental Entomology 40: 633-638.

Reed DK, Reed GL, Creighton CS. 1986. Introduction of entomogenous nematodes into trickle irrigation systems to control striped cucumber beetle (Coleoptera, Chrysomelidae). Journal of Economic Entomology 79: 1330-1333.

Simon M, Synder J. 2005. Organic management of cucumber beetles in cucurbits. Grants and Education to Advance Innovations in Sustainable Agriculture. SARE project-LS01-127. (12 Sep 2013)

Sorensen KA. 1999. Cucumber beetles, Coleoptera: Chrysomelidae. Greenshare fact sheets. University of Rhode Island Landscape Horticulture Program. (12 Sep 2013)

Synder W. 2012. Managing cucumber beetles in organic farming systems. Cornell University Corporative Extension. (12 Sep 2013)

Snyder WE, Wise DH. 2000. Antipredator behavior of spotted cucumber beetles (Coleoptera: Chrysomelidae) in response to predators that pose varying risks. Environmental Entomology 29: 35-42.

Tallamy DW, Whittington DP, Defurio F. 1998. Sequestered cucurbitacins and pathogenicity of Metarhizium anisopliae (Moniliales: Moniliaceae) on spotted cucumber beetle eggs and larvae (Coleoptera: Chrysomelidae). Environmental Entomology 27: 366-372.

Toepfer S, Haye T, Erlandson M, Goettel M, Lundgren JG, Kleespies RG, Weber DC, Cabrera Walsh G, Peters A, Ehlers R-U, Strasser H, Moore D, Keller S, Vidal S, Kuhlmann U. 2009. A review of the natural enemies of beetles in the subtribe Diabroticina (Coleptera: Chrysomelidae): implications for sustainable pest management. Biocontrol Science and Technology 19: 1-65.

Webb S. 2010. Insect management for cucurbits (Cucumber, Squash, Cantaloupe, and Watermelon). ENY-460.
Entomology and Nematology Department, Florida Cooperative Extension Service, IFAS, University of Florida, Gainesville, FL. (12 Sep 2013)

Williams JL, Wise DH. 2003. Avoidance of wolf spiders (Araneae: Lycosidae) by striped cucumber beetles (Coleoptera: Chrysomelidae): laboratory and field studies. Environmental Entomology 32: 633-640

Yardim EN, Arancon NQ, Edwards CA, Oliver TJ, Byrne RJ. 2006. Suppression of tomato hornworm (Manduca quinquemaculata) and cucumber beetles (Acalymma vittatum and Diabotrica undecimpunctata) populations and damage by vermicomposts. Pedobiologia 50: 23-29.

Zehnder G, Kloepper J, Yao CB, Wei G. 1997. Induction of systemic resistance in cucumber against cucumber beetles (Coleoptera: Chrysomelidae) by plant growth-promoting rhizobacteria. Journal of Economic Entomology 90: 391-396. 